\title{
Nonmarketability and the Value of Employee Stock Options
}

\author{
Menachem Abudy \\ School of Business Administration \\ Bar-Ilan University, Israel \\ abudym@mail.biu.ac.il
}

Simon Benninga

Faculty of Management

Tel Aviv University, Israel

benninga@post.tau.ac.il

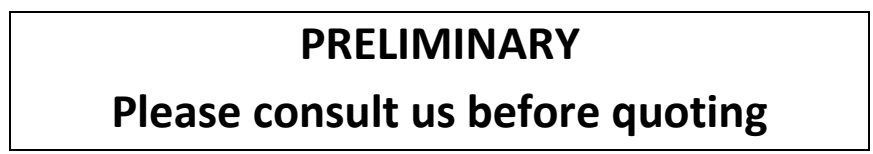

ABSTRACT

This paper uses the Benninga-Helmantel-Sarig (2005) framework to value employee stock options (ESOs) in a framework which takes explicit account of employee nondiversification in addition to the standard features of vesting and forfeit (or forced exercise) of the stock options. This framework provides an endogenous explanation of early exercise of employee stock options, has a computational advantage over existing utility maximizing models, and also allows us to quantify the nondiversification effects. Using a proprietary dataset which contain 33,294 ESO exercise records at sixty five publically traded firms between 1993-2009 (both executive and non-executive employees), we measure the nonmarketability associated with untradeable stock options, and use it to value ESOs. We find that the private pricing model value on the grant date is about $50 \%$ less than the value of a plain vanilla Black-Scholes option value. We also find that the private pricing model is aligned with empirical findings of ESOs. This pricing framework provides an exercise boundary of ESOs and can also serve as an approximation to the fair value estimation of share based payment granted to employee and executive.

JEL classification: G12, G13, G32.

Keywords: Employee stock options, under pricing.

We thank Tamir Fishman \& Co. for providing the data used in this study, with special thanks to Yaniv Shirion from Tamir Fishman for his assistance and effort with the data. We thank the seminar participants of Oxford financial research centre, University of Piraeus, the Norwegian University of Science and Technologies, BI Norwegian School of management, Otago University, Monash University, University of Melbourne, Australian National University, University of New South Wales, Tel-Aviv University, Ben Gurion University, Bar-Ilan University, Haifa University and the participants at the Arne Ryde Workshop in Financial Economics at Lund University, the Israeli ORSIS (Operations research society) meeting and the EBES 2009 conference. We thank to the Henry Crown Institute of Business Research in Israel of Tel Aviv University for financial support. 


\section{Nonmarketability and the Value of Employee Stock Options}

\section{Introduction}

A large body of existing literature deals with the pricing and economic implications of employee stock options (ESOs). ESOs are basically financial derivatives in incomplete markets and should be priced as such (Grasselli, 2005). In this paper we extend this literature to consider the impact of nonmarketability on this share-based payment, by employing a model first developed by Benninga, Helmantel, Sarig (BHS, 2005). Our model also allows us to consider differential access to capital markets of employees and the firm.

An employee stock option has special characteristics: It has a vesting period-a period in which the employee cannot exercise the stock option. Upon job termination taking place during the vesting period, the options are forfeited. In contrast, job termination after the vesting period usually means the employee cannot continue to hold the stock options (typically, exercise is required within 90 days after the job termination date). In addition, ESOs are nontransferable and the employee is not allowed to hedge his ESOs by taking short positions in the firm's stock (Leon et al. 2009). ${ }^{1}$ The nontransferability and nonhedgeability features cause to early exercise of the stock options and also contribute to the fact that ESOs has no market price.

Generally, ESO valuation models can be divided into three categories: Utility maximizing models, lattice-based models, and continuous-based models. Utility maximizing models use a risk-averse utility function, and derive the employee's certainty equivalent to establish whether the employee exercises the stock option (before maturity). Lattice-based models are usually modifications of the Cox-Ross-Rubinstein (1979) binomial framework, with an exogenous early exercise decision, and continuous-based models are typically modifications of the Black-Scholes (1973) model, and also include exogenous early exercise decision.

The use of the BHS (2005) model for ESO valuation incorporates the nonmarketability effect into ESO pricing. The model uses private state prices, which are the appropriate state prices for risk-averse employees who are restricted in their diversification, and are therefore exposed to some of the firm's specific risk.

The private pricing model has two advantages over existing approaches in pricing ESOs. First, compared to lattice and continuous-time models, the private pricing model provides an

\footnotetext{
1 See Section 16(c) of the U.S. Securities Exchange Act. In addition, Paragraph B80 in FAS 123(R) mentions that "Federal securities law precludes certain executives from selling shares of the issuer's stock that they do not own, and the Board understands that many public entities have established share trading policies that effectively extend that prohibition to other employees".
} 
endogenous explanation of ESO early exercise. While the early exercise phenomenon of ESOs is widely documented, most ESO pricing models, such as the Hull and White (2004) model, employ an arbitrary algorithm to explain early exercise. ${ }^{2}$ Compared to the utility maximizing models, which provide endogenous early exercise decision, the private pricing model can be viewed as a model that incorporates the utility model parameters into a single factor, thus providing a simplified and more flexible approach to describing exercise behavior and to computing the ESO value. ${ }^{3}$ In this respect, pricing ESO using the private pricing model combines the flexibility of the binomial model along with a theoretical framework which models the behavioral approach that characterizes utility maximizing models. We show that the use of the BHS model is aligned with empirical findings in studies on ESO databases: The ratio of the stock price to exercise price and the foregone value (in percentages), compared to the BS value (both on the exercise date) are within the range of empirical estimations. The employee tends to exercise earlier as more restrictions are added to the stock options, if he is more undiversified, and when the stock's volatility is higher. Additional advantage of the private pricing model in pricing ESOs is that we are able to quantify the nondiversification effects.

In the second part of the paper we use a proprietary data set obtained from Tamir Fishman \& Co. for estimating the nondiversification measure. ${ }^{4}$ This comprehensive stock option database is comprised of complete histories of stock option grants, vesting structures, option exercises, and cancellation events for all employees in sixty-five firms. The stock option grant sample period is between 1993 and 2009, and the exercise record sample period is between 1998 and 2009. Tamir Fishman supplied this data on the condition that the companies and their employees' identity remain anonymous.

We use 33,294 ESOs exercise records from sixty five firms in order to estimate the nondiversification measure associated with the private pricing model. We calibrate the stock price on the exercise date, accompanied by the specific characteristics of each exercise record-such as the annual risk free rate, historical volatility and remaining time to maturityand estimates the nondiversification measure for each exercise record. Then, we calibrate this nondiversification estimation and value the stock option on the grant date using the specific characteristics of the stock option on the grant date. We find that the value of the stock option is about $50 \%$ less than a plain vanilla stock option value, calculated by the Black-Scholes option pricing model. This discount varies between industries and rank of employees.

\footnotetext{
${ }^{2}$ Hull and White (2004) assume that the holder of an ESO will exercise his option if the stock price $S_{t}$ is a multiple $m$ of the option exercise price $X$. A common value for $m$ is 2 , but this is somewhat arbitrary. As we show in Section 2.2 , in our model early exercise is endogenous.

${ }^{3}$ The utility-maximizing approach requires explicit specification of variables, such as the employee's risk aversion level, her private wealth, the proportion of her private wealth compared to her option wealth, the way in which her private wealth is invested, etc. This, in addition to the computational difficulty, makes it reasonable to assume that utility-based models would not be common in practice (Chance 2004).

${ }^{4}$ Tamir Fishman \& Co. is an Israeli-based investment house which offers management services of share-based compensation programs.
} 
The economic implications of the use private pricing model in share-based payments valuation are significant. According to the literature, the objectives of stock option plans are to assist the company attract, retain, and motivate its executives and other employees. ${ }^{5}$ Options assist companies attract executives, provide retention incentives using a combination of vesting provisions and long option terms, motivate executives and other employees by providing a link between company performance and the employee's wealth, and in addition to these stated objectives, serves as substitute to cash compensation. As a result, ESO compensation has economic implications to a wide variety of affairs, ranging from incentive and option design to employee (or executive) behavior and compensation packages. ${ }^{6}$

A common claim against applying the nonmarketability discount in valuation models is that several alternatives exist to hedge the individual's exposure, which can reduce on the degree of nonmarketability. This claim is also addressed to employees, since equity-based compensation imposes them to be undiversified. ${ }^{7}$ The first hedging strategy is short sale the firm's security. This alternative, however, is not effective since employees who are granted ESOs are prohibited from short selling their company's stock. ${ }^{8}$ In addition, this alternative may not be effective if the amount of securities held by the employee is fairly large or if the market for the underlying is not liquid. An additional hedging alternative is zero-cost or cashless collar obtained from investment banks (Meulbroek, 2001). This alternative may be impossible to implement if there are no options trading on the underlying, when the amount of securities held by the employee is large or when the nonmarketability restriction period has no parallel options available. In addition, in reality the exercise prices are typically set sufficiently far from the current market price so that the IRS will not consider this a constructive sale of the underlying security (Tabak, 2003). Bettis, Bizjak and Lemmon (2005) report that the number of such transactions reported to the SEC has so far been relatively small. In addition, the evidence if the use of this hedging strategy in practice, regards mainly to executives holding restricted stocks and not stock options, and not a common practice which is offered to all the employees of the granting firm (for example, Meulbroek discusses only on executives). A third alternative is to buy an equity swap of the relevant index or portfolio of the matching industry. This alternative provides only partial hedging, and may have tax consequences ((Meulbroek 2001, Tabak 2003). Additional hedging alternative is to short the index in which the company's stock is traded in (such as the S\&P 500 futures). However, few managers appear to engage in such

\footnotetext{
${ }^{5}$ For an elaborate discussion see Hall and Murphy (2002). In addition, Ittner et al (2004) summarize the relative importance of self-reported objectives of employee stock options plans.

${ }^{6}$ See Hall and Murphy (2002) provide an elaborate discussion on the economic implications of ESO valuation.

${ }^{7}$ Employees typically have a higher exposure to the firm's risk, since in addition to equity-based compensation rewards, their future wealth and consumption is also affected from the salary they receive from the same firm.

${ }^{8} \mathrm{An}$ employee is not allowed to hedge his position by taking short positions in the firm's stock. Section 16 (c) of the U.S. Securities Exchange Act relates to the firm's executives, and paragraph B80 in FAS 123(R) mentions that "the Board understands that many public entities have established share trading policies that effectively extend that prohibition to other employees".
} 
transactions, perhaps because of the liquidity risk of this strategy (index futures are mark to market daily). In addition, this strategy offers only partial hedging. Overall, it seems that the possibility of hedging ESO provides only partial solution, with little evidence to be executed in practice.

The structure of this paper is as follows: Section 2 presents the implications of Benninga-Helmantel-Sarig (2005) model and studies its implications on employee stock option pricing. Section 3 presents the employee stock option sample database. Section 4 uses sample data to measure the nonmarketability of the pricing model. Section 5 implement the model and compares its implications to empirical findings. Section 6 concludes.

\section{Imperfect markets, nondiversification, and the valuation of ESOs}

\section{The model}

We use a model developed by Benninga, Helmantel, and Sarig (BHS, 2005) to represent the impact of nondiversification on pricing. The BHS model represents pricing in a binomial framework and assumes that the nondiversified consumer has too much consumption in the good states and too little consumption in the bad states of the world. The resulting state prices of a nondiversified consumer will be lower than the market state prices in good states and higher than the market prices in bad states. ${ }^{9}$

Let $\left\{q_{u}, q_{d}\right\}$ represent the public price of $\$ 1$ in an up/down state world, and let $\left\{p_{u}, p_{d}\right\}$ represent the private price of $\$ 1$ in an up/down state world, respectively. We assume that firms use the public state prices for valuation, whereas employees use the private state prices.

We assume that:

$q_{u} \cdot U+q_{d} \cdot D=1$

$q_{u}+q_{d}=p_{u}+p_{d}=1 / R$

$p_{u}<q_{u}, p_{d}>q_{d}$

$p_{u}=q_{u}-\delta$

$p_{d}=q_{d}+\delta$

where $R$ is the gross one period interest rate, $U$ is the gross one period move-up factor and $D$ is the gross one period move-down factor (in percentage). $U, D$, and $R$ are related to the size of the interval $\Delta t$, but for simplicity we have repressed this relationship in our notation. For completeness, if $U$ and $D$ are derived from a lognormal process with annual mean $\mu$ and standard deviation $\sigma$, then $U=\exp [\mu \Delta+\sigma \sqrt{\Delta t}], D=\exp [\mu \Delta-\sigma \sqrt{\Delta t}]$, and $R=\exp [r \Delta t] . \delta$ is the spread between the public and the private state prices (this is the nondiversification measure).

\footnotetext{
${ }^{9}$ State prices are the marginal rates of substitution adjusted for the employee's state probabilities and pure rate of time preference.
} 
The use of the same state prices by both the firm and employees assumes that the employees can trade freely in all the assets in the market (i.e., can create long and short positions). Differentiating between public and private state prices allows us to drop this assumption. Essentially, we assume that-as a result of trading and hedging restrictions on option grants-risk-averse employees are restricted in their diversification and are therefore exposed to some of the firm's specific risk. The limitations on the stock option granted to the employee and on the employee hedging activity are designated to tie the employee to firm performance. ${ }^{10}$ The technical meaning of the above assumptions is that both private and public state prices assume equal access to the borrowing/lending market and hence face the same borrowing rate. However, the private price for the up state $p_{u}$ is lower than the public price for the same state $q_{u}$ and the private price for the down state $p_{d}$ is higher than the public price for the same state $q_{d}$.

If state prices are computed using the probability-adjusted marginal rates of substitution, then the condition $p_{u}<q_{u}, p_{d}>q_{d}$ can be interpreted as meaning that the employee would like to transfer consumption from the good state to the bad state: Relative to his optimal consumption pattern, an employee has too much consumption in the good state and too little consumption in the bad state. $\delta$ is the spread between the public and private state prices that captures the nondiversification measure of the employee. In other words, $\delta$ represents the higher tolerance to the firm's risk of the well-diversified investor than that of the incompletely diversified employee (BHS 2005). ${ }^{11}$

Since $p_{u}<q_{u}$ and since an employee stock option pays off in the up states, it is obvious that the private valuation of an ESO is less than the public valuation since the option pays off in the up states. This characteristic has been proved for stocks in BHS (2005).

The effect of nonmarketability on stock options (with a marketable underlying asset) can be significant. For example, Brenner et al. (2001) studied nontraded currency options and concluded that they traded at a discount of approximately $21 \%$, relative to otherwise similar liquid options. Eldor et al. (2006) investigate nontradeable and tradeable identical Treasury derivatives. They find that nontradability is significant and covaries positively with interest rate volatility. This issue is of particular relevance in the valuation of employee stock options that are offered as compensation at publicly traded companies (Damodaran, 2005). Meulbroek (2001) computes a lower bound to the value managers attribute to their stock options. These

\footnotetext{
${ }^{10}$ This is the most common justification given by firms for employee stock options (Damodaran 2005).

${ }^{11}$ Bick (1987) shows that geometric Brownian motion for a stock price is compatible with a utility function if and only if the utility function exhibits constant relative risk aversion and the consumption process is multiplicative. It follows that only in the cases described by Bick is the Black-Scholes pricing for European options underpinned by utility foundations. Note that any binomial model and any utility function necessarily give rise to a set of state prices and a (binomial) pricing function for options. However, only in the case that the Bick assumptions hold (they evidently do not in the private pricing model) do we get Black-Scholes.
} 
These managers are assumed to hold an undiversified portfolio with a concentrated exposure to the employer's stock. According to Muelbroek's estimation, a manager of a NYSE firm with all his assets tied to her firm would value typical options (a vesting period of 3 years) at $70 \%$ of their market value. For entrepreneurially-based firms, such as internet companies or new economy firms, (with higher stock volatility), Meulbroek estimates that an undiversified manager (with all his assets tied to the share price) would value options at $53 \%$ of their cost to the granting firm. Changing the manager's level of diversification causes only minor changes in the valuation gap (for example, assuming the internet manager's firm holds $50 \%$ of his wealth outside the firm increases the option value to $59 \%$ from the cost to the granting firm). ${ }^{12}$

\section{ESOs valuation using the private pricing model}

We use the private pricing model to value ESOs, considering the following characters:

Vesting period: We incorporate vesting period in the valuation model. During this period, the employee cannot exercise the stock option.

Exit rate: We consider the possibility that the employee may leave the firm by employing an exit rate during the option life. The probability the employee leaves the company is modeled by an annual exit rate $e$ and can be determined for each period of time $\Delta t$ as 1- $e \Delta t$. If the employee leaves the company during the vesting period, the unvested options are forfeited and the exit value is zero.

Forced exercise: The exit rate is also incorporated after the vesting period. ${ }^{13}$ In this case, if the employee leaves the company he will receive an exit value of $\operatorname{Max}\left(S_{t}-X, 0\right)$. This action reflects the common practice of forced exercise upon job termination after vesting (usually over a period of 90 days).

Nonmarketability: By the term nonmarketability, we refer to the fact that employee stock options are nontradable and nonhedgeable, and therefore cause deviations from diversification to the employee. We use the private pricing model to incorporate this fact in the valuation model. Private pricing is being used before and after vesting, reflecting the fact that the employee cannot trade or hedge the stock option throughout the entire holding period. ${ }^{14}$

In this respect, Chance and Yang (2004) mention the fact that it is not at all clear that riskneutral valuation, incorporated in the public state prices $\left\{q_{u}, q_{d}\right\}$, is appropriate for

\footnotetext{
${ }^{12}$ We can also use the private pricing model to value restricted stocks or restricted stocks units. In this case, the stock is restricted only during the vesting period; we can use the private state prices during this period and public state prices subsequently. Consistent with the literature (Longstaff 1995 and Damodaran 2005), we find that longer vesting period leads to higher discounts for nonmarketability.

${ }^{13}$ We choose to use the same exit rate before and after vesting. Changing this assumption will adjust the stock option value accordingly.

${ }^{14}$ According to Section 16(c) of the U.S. Securities Exchange Act, executives are precluded from short-selling the shares of their employer. The FAS 123R (paragraph B80) indicates that "many public entities have established share trading policies that effectively extend that prohibition to other employees". (See Leung and Sircar 2007b)
} 
accommodating risks, such as forfeiture and early exercise. These risks are not irrelevant, probably not diversifiable, and almost surely do not have a zero market price of risk.

Life Term: We use the contractual life term of the ESO. The use of expected life term in ESO pricing is misleading, since the fact that the option is nonmarketable causes to early exercise. Putting differently, we are interested to price ESO directly, and not using expected life which is being caused as result of trading and hedging restrictions. The use of private state prices allows us to estimate the expected life term of the option endogenously.

\section{Valuation effects of public versus private state pricing}

Figure 1 shows the valuation of an European plain-vanilla call option using the BlackScholes model (BS), public state prices (i.e., the binomial model) and using private state prices (in a binomial framework). The graphs assume that both the private and public prices face the same interest rate, so that $q_{U}+q_{D}=p_{U}+p_{D}$.

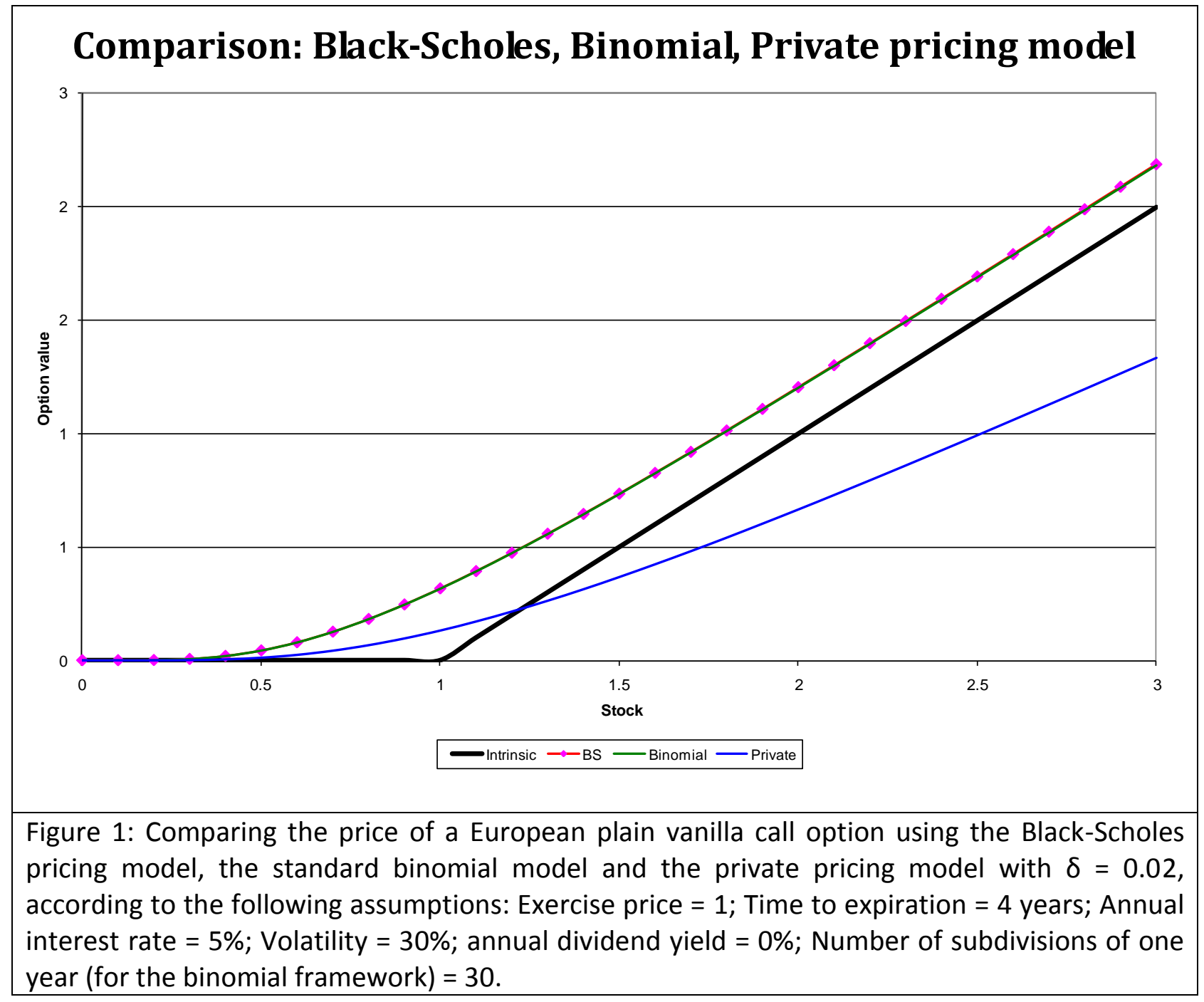


Figure 2 presents the estimation of European plain vanilla call options for different values of $\delta$.

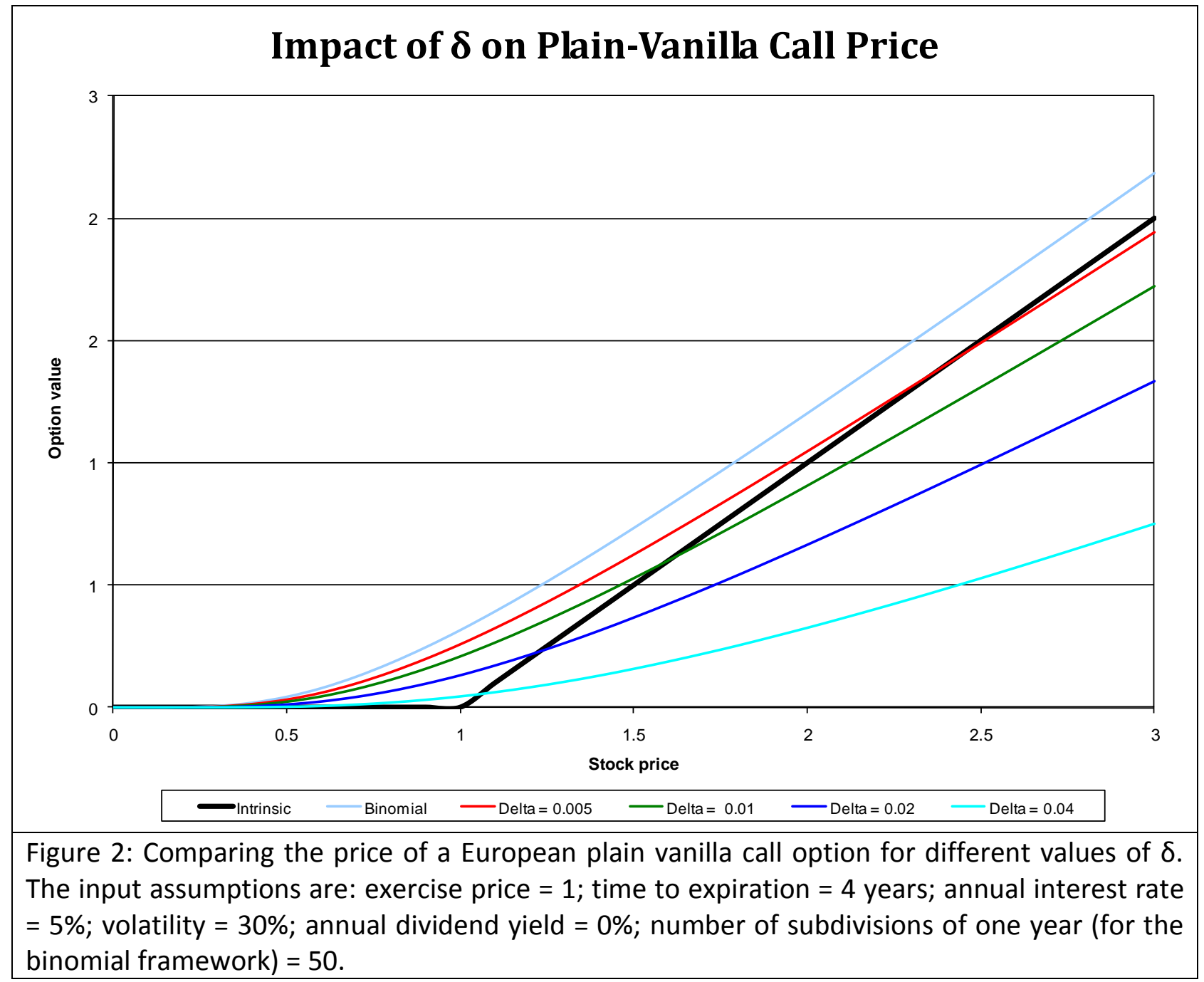

From Figures 1 and 2, it is clear that the private pricing model leads to possible earlyexercise of American plain-vanilla calls on non-dividend-paying stocks. This outcome is different from classical option pricing theory, and it is due to the nondiversification of the option holder. It is thus also clear that this model leads to endogenous early exercise for employee stock options. Figure 3 presents the ESO value, calculated using the private pricing model, with different stock option characteristics. 


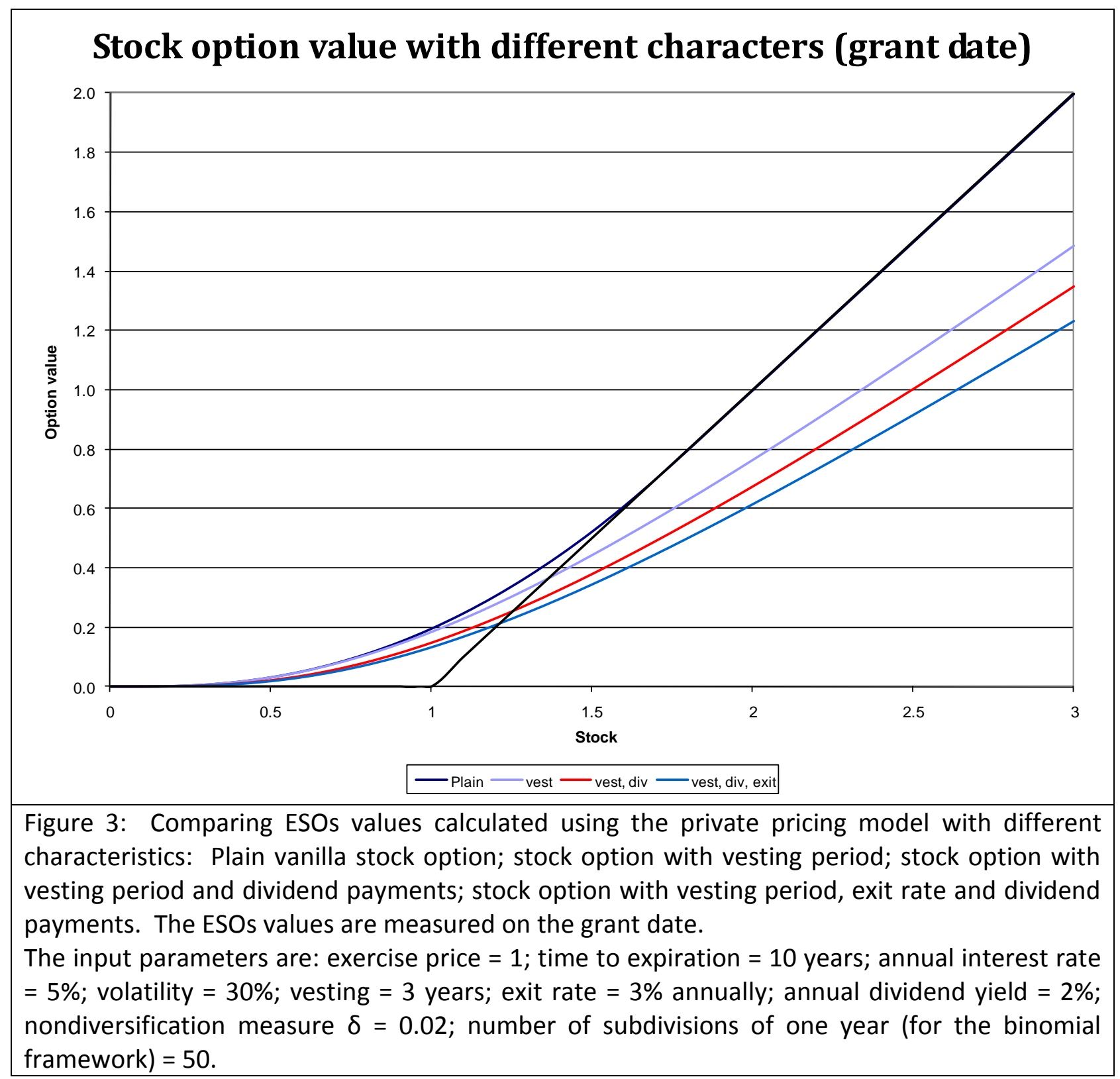

Figure 3 shows that as more limitations are added to the stock options, the employee tends to exercise earlier. In other words, the employee will attribute a lower value to the stock option as more limitations are added.

\section{Data}

We use a proprietary data set that was obtained from Tamir Fishman \& Co., an Israelibased investment house, which offers management services of share-based compensation programs. Tamir Fishman supplied this data on the condition that the companies and their 
employees' identity remain anonymous. In this respect, we identify the companies by a twodigit code.

The stock option database is comprised of complete histories of stock option grants, vesting structures, option exercises and cancellation events for all employees in both private and public firms. We identify ninety-two firms that are either currently public, were public in the past or were acquired by a public firm and now serve as its subsidiary. After processing the data (specified below), we are left with sixty-five firms. The ESO grants sample period is between 1993 and 2009, and the exercise records period is between 1998 and 2009.

The unit of analysis is based on employee-by-employee exercise records. We clean the data by performing the following (which resulted in reducing twenty seven firms from the sample):

- Exclude exercise records which represent forced exercise. Forced exercise can usually result from job termination and from mergers and acquisitions. ${ }^{15}$ Since we are interested in voluntary exercise records, we exclude all exercise records that were made 100 days before or after the employee job termination. This period is align with the common practice is to allow employees up to three months to exercise their stock options after they cease working in the company. We exclude 100 days preceding the job termination to account for the case that the employee exercises his stock option as part of his plan to cease working in the company.

- Exclude exercise records in case the grant date occurred prior to the firm's IPO

- Exclude exercise records of nonemployees.

- Exclude exercise records with exercise price lower than 0.1(such ESOs are parallel to restricted stock units).

- Exclude exercise records in case less than 50 stocks were exercised.

- We required a minimum of 14 trading days in a month for volatility estimation, and exclude exercise records in months that violate this criterion.

- Due to insufficient data of ESOs grants before 2000, we excluded exercise records of exemployees with option life of less than three years, in which the original expiration date is identical to the last date of exercise. We also excluded exercise records in which the gap between the original expiration date and the grant date was less than four years.

- Lastly, we exclude ESO exercise records that were 100 days before the option expiration date, since such exercise pattern does not suitable early exercise patterns. In other words, employees which hold their stock options until expiration did not signal on their value by early exercising and therefore bias the nondiversification estimation.

\footnotetext{
${ }^{15}$ Forced exercise due to job termination or as a result of mergers and acquisitions is a common practice. In case a company did not force early exercise and the employee exercised his stock option after 100 days from the job termination, we did not exclude this exercise records from the sample.
} 
We use the stock returns and risk-free discount rates in the pricing procedure. We obtain Stock prices from CRSP, Tel-Aviv stock exchange (TASE) website, Yahoo! Finance and websites of the companies themselves. We used these stock prices to calculate historical volatility, based on the daily continuous compounded return of a minimum estimation period of 20 trading days from the firm's IPO (subject to 14 trading days in a month restriction), expanding the estimation window to 30 days and then used a rolling window estimation of 30 trading days. ${ }^{16}$ As a proxy for the annual risk-free interest rates we use the short-term discount rates that match to the currency that the firm's stock is traded. These discount rates were obtained from the Federal Reserve Statistical Release website ( 3 months T-bill); the Bank of Israel website (MAKAM rates); and the European central banks websites. In addition, we assumed a zero dividend yield for the entire sample firms (this assumptions fits $80 \%$ of the sample firms' behavior during their life) and a vesting period of three years (an assumption which is relevant only to the ESO estimation on the grant date).

\section{Sample description}

The final sample contains 33,294 exercise records from sixty five companies. Table 1 provides a description of the companies industries according to the two-digit firm-level SIC codes as appears in CRSP. There is a considerable heterogeneity in the firm industries type in the sample. In addition, a major part of the firms comprising the dataset are new-economy firms related to computers, software, the internet, telecommunications or networking. ${ }^{17}$ These new economy firms represent $69.23 \%$ from the firms and $73.83 \%$ of the exercise records in the sample.

\footnotetext{
${ }^{16}$ We repeat the historical volatility estimation using 126 trading days. The results are similar.

17 New economy firms defined as companies with primary SIC codes 3570, 3571, 3572, 3576, 3577, 3661, 3674, 4812, 4813, 5045, 5961, 7370, 7371, 7372 and 7373 (See Hall and Murphy 2003).
} 


\begin{tabular}{|c|c|c|c|}
\hline \multicolumn{4}{|c|}{ Table 1: Description of sample firms } \\
\hline Industry & $\begin{array}{l}\text { Two- } \\
\text { digit } \\
\text { firm- } \\
\text { level } \\
\text { SIC } \\
\end{array}$ & $\begin{array}{l}\text { Percentage } \\
\text { (number } \\
\text { of firms) }\end{array}$ & $\begin{array}{l}\text { Percentage } \\
\text { (number of } \\
\text { employees) }\end{array}$ \\
\hline Food and kindred products & 20 & $1.54 \%$ & $0.16 \%$ \\
\hline Paper and allied products & 26 & $1.54 \%$ & $0.73 \%$ \\
\hline $\begin{array}{l}\text { Printing, publishing, and allied } \\
\text { industries }\end{array}$ & 27 & $1.54 \%$ & $0.17 \%$ \\
\hline Chemicals and allied products & 28 & $3.08 \%$ & $0.39 \%$ \\
\hline $\begin{array}{l}\text { Industrial and commercial } \\
\text { machinery and computer } \\
\text { equipment }\end{array}$ & 35 & $16.92 \%$ & $28.71 \%$ \\
\hline $\begin{array}{l}\text { Electronic and other electrical } \\
\text { equipment and components, } \\
\text { except computer equipment }\end{array}$ & 36 & $26.15 \%$ & $38.48 \%$ \\
\hline $\begin{array}{l}\text { Measuring, analyzing, and } \\
\text { controlling instruments; } \\
\text { photographic, medical and } \\
\text { optical goods; watches and } \\
\text { clocks }\end{array}$ & 38 & $7.69 \%$ & $7.22 \%$ \\
\hline Communications & 48 & $7.69 \%$ & $7.73 \%$ \\
\hline $\begin{array}{l}\text { Wholesale trade-durable } \\
\text { goods }\end{array}$ & 50 & $1.54 \%$ & $0.20 \%$ \\
\hline Depository institutions & 60 & $1.54 \%$ & $2.09 \%$ \\
\hline Business services & 73 & $26.15 \%$ & $6.64 \%$ \\
\hline $\begin{array}{l}\text { Engineering, accounting, } \\
\text { research, management, and } \\
\text { related services }\end{array}$ & 87 & $4.62 \%$ & $7.48 \%$ \\
\hline $\begin{array}{l}\text { This table provides a summary } \\
\text { sample firms from the Tamir Fi } \\
\text { are organized by the two-digit } \\
\text { CRSP }\end{array}$ & n-leve & $\begin{array}{l}\text { e relevant inc } \\
\text { ase. The sum } \\
\text { C categories }\end{array}$ & $\begin{array}{l}\text { ustries of the } \\
\text { nary statistics } \\
\text { is reported in }\end{array}$ \\
\hline
\end{tabular}

Tables 2 and 3 present summary statistics on the time to maturity (in years) of the stock options (i.e. it's the contractual option life) and on the remaining time to maturity (in years) of the stock options on the exercise date, respectively. These characters are used to estimate the value of the nondiversification measure $\delta$ on the exercise date and the option value on the grant date. Table 2 presents a quite homogeneous picture: The average contractual option life ranges between eight to ten years, with some options grants for 16 years. The minimum period in the sample is four years. Combined with the data of Table 3, the data indicates that on average the ESOs in the sample are exercised when there are nearly two-thirds to half of the option term remaining. These findings are consistent with the findings of Huddart and Lang 
(1996) and Carpenter et al. (2009). The sectors that deviate from this early exercise pattern are the food and kindred products and the paper and allied products (SIC codes 20 and 26, respectively). 


\begin{tabular}{|c|c|c|c|c|c|c|}
\hline \multicolumn{7}{|c|}{ Table 2: Maturity (in years) of the sample option } \\
\hline Industry & Average & SD & Max & Min & $\begin{array}{c}\text { 1st } \\
\text { quartile }\end{array}$ & $\begin{array}{c}\text { 4th } \\
\text { quartile }\end{array}$ \\
\hline Full sample & 8.087 & 1.918 & 16.008 & 4.003 & 6.005 & 10.005 \\
\hline Food and kindred products & 6.283 & 0.931 & 8.005 & 4.268 & 5.851 & 6.923 \\
\hline Paper and allied products & 5.225 & 0.839 & 9.005 & 4.003 & 5.003 & 5.003 \\
\hline $\begin{array}{l}\text { Printing, publishing, and } \\
\text { allied industries }\end{array}$ & 10.008 & 0.001 & 10.008 & 10.005 & 10.008 & 10.008 \\
\hline $\begin{array}{l}\text { Chemicals and allied } \\
\text { products }\end{array}$ & 10.023 & 0.039 & 10.181 & 10.005 & 10.005 & 10.008 \\
\hline $\begin{array}{l}\text { Industrial and commercial } \\
\text { machinery and computer } \\
\text { equipment }\end{array}$ & 7.162 & 1.571 & 10.507 & 4.123 & 6.003 & 8.003 \\
\hline $\begin{array}{l}\text { Electronic and other } \\
\text { electrical equipment and } \\
\text { components, except } \\
\text { computer equipment }\end{array}$ & 9.091 & 1.511 & 16.008 & 4.003 & 7.164 & 10.008 \\
\hline $\begin{array}{l}\text { Measuring, analyzing, and } \\
\text { controlling instruments; } \\
\text { photographic, medical and } \\
\text { optical goods; watches and } \\
\text { clocks }\end{array}$ & 5.785 & 1.628 & 10.008 & 4.003 & 5.000 & 5.003 \\
\hline Communications & 9.751 & 0.572 & 10.008 & 5.849 & 10.005 & 10.005 \\
\hline $\begin{array}{l}\text { Wholesale trade-durable } \\
\text { goods }\end{array}$ & 9.312 & 1.270 & 10.433 & 6.499 & 9.501 & 10.005 \\
\hline Depository institutions & 5.741 & 0.761 & 7.247 & 4.003 & 6.000 & 6.000 \\
\hline Business services & 9.032 & 1.844 & 10.008 & 4.003 & 9.871 & 10.008 \\
\hline $\begin{array}{l}\text { Engineering, accounting, } \\
\text { research, management, } \\
\text { and related services }\end{array}$ & 6.938 & 0.679 & 10.008 & 4.044 & 7.003 & 7.005 \\
\hline Entire sample, employees & 8.066 & 1.921 & 16.008 & 4.003 & 6.005 & 10.005 \\
\hline $\begin{array}{l}\text { Entire sample, executives } \\
\text { (Directors and Officers) }\end{array}$ & 8.684 & 1.728 & 10.079 & 4.003 & 7.005 & 10.008 \\
\hline $\begin{array}{l}\text { Entire sample, exercise } \\
\text { (cash) }\end{array}$ & 8.941 & 1.809 & 16.008 & 4.003 & 7.045 & 10.008 \\
\hline $\begin{array}{l}\text { Entire sample, SDS (same } \\
\text { day sale) }\end{array}$ & 8.080 & 1.917 & 16.008 & 4.003 & 6.005 & 10.005 \\
\hline \multicolumn{7}{|c|}{$\begin{array}{l}\text { This table reports the time to maturity of the option grants on the grant date. The time } \\
\text { to maturity is measured as the number of years between the grant date and the } \\
\text { expiration date of the option. The summary statistics are computed over all the exercise } \\
\text { records in the sample period. The summary statistics is organized by the two-digit firm- } \\
\text { level SIC categories as reported in CRSP. }\end{array}$} \\
\hline
\end{tabular}




\begin{tabular}{|c|c|c|c|c|c|c|}
\hline \multicolumn{7}{|c|}{$\begin{array}{l}\text { Table 3: Time to maturity of the sample options (in years) on } \\
\text { the exercise date }\end{array}$} \\
\hline Industry & \begin{tabular}{|c|}
$\begin{array}{c}\text { Averag } \\
\text { e }\end{array}$ \\
\end{tabular} & SD & Max & Min & $\begin{array}{c}\text { 1st } \\
\text { quartile }\end{array}$ & 4th quartile \\
\hline Full sample & 4.669 & 2.334 & 9.978 & 0.274 & 2.871 & 6.564 \\
\hline Food and kindred products & 1.868 & 0.770 & 2.975 & 0.529 & 1.104 & 2.555 \\
\hline Paper and allied products & 1.527 & 0.768 & 4.003 & 0.288 & 0.852 & 1.979 \\
\hline $\begin{array}{l}\text { Printing, publishing, and } \\
\text { allied industries }\end{array}$ & 7.068 & 0.735 & 8.553 & 5.441 & 6.679 & 7.512 \\
\hline $\begin{array}{l}\text { Chemicals and allied } \\
\text { products }\end{array}$ & 6.949 & 1.467 & 9.373 & 0.630 & 6.370 & 7.904 \\
\hline $\begin{array}{l}\text { Industrial and commercial } \\
\text { machinery and computer } \\
\text { equipment }\end{array}$ & 3.831 & 2.036 & 9.318 & 0.274 & 2.373 & 4.981 \\
\hline $\begin{array}{l}\text { Electronic and other } \\
\text { electrical equipment and } \\
\text { components, except } \\
\text { computer equipment }\end{array}$ & 5.417 & 2.129 & 9.948 & 0.274 & 4.025 & 7.167 \\
\hline $\begin{array}{l}\text { Measuring, analyzing, and } \\
\text { controlling instruments; } \\
\text { photographic, medical and } \\
\text { optical goods; watches and } \\
\text { clocks }\end{array}$ & 2.417 & 1.955 & 9.781 & 0.274 & 0.923 & 2.836 \\
\hline Communications & 6.679 & 1.638 & 9.948 & 0.282 & 5.841 & 7.879 \\
\hline $\begin{array}{l}\text { Wholesale trade-durable } \\
\text { goods }\end{array}$ & 8.493 & 1.093 & 9.663 & 5.975 & 8.600 & 8.992 \\
\hline Depository institutions & 3.101 & 1.317 & 6.197 & 0.395 & 1.962 & 4.196 \\
\hline Business services & 5.973 & 2.194 & 9.978 & 0.282 & 4.460 & 7.674 \\
\hline $\begin{array}{l}\text { Engineering, accounting, } \\
\text { research, management, and } \\
\text { related services }\end{array}$ & 3.506 & 1.439 & 9.266 & 0.282 & 2.577 & 4.490 \\
\hline Entire sample, employees & 4.630 & 2.333 & 9.978 & 0.274 & 2.830 & 6.460 \\
\hline $\begin{array}{l}\text { Entire sample, executives } \\
\text { (Directors and Officers) }\end{array}$ & 5.749 & 2.115 & 9.748 & 0.477 & 4.013 & 7.504 \\
\hline $\begin{array}{l}\text { Entire sample, exercise } \\
\text { (cash) }\end{array}$ & 5.238 & 2.399 & 9.660 & 0.282 & 3.586 & 7.274 \\
\hline $\begin{array}{l}\text { Entire sample, SDS (same } \\
\text { day sale) }\end{array}$ & 4.664 & 2.333 & 9.978 & 0.274 & 2.866 & 6.554 \\
\hline \multicolumn{7}{|c|}{$\begin{array}{l}\text { This table provides the summary statistics over the sample period for the remaining term (in } \\
\text { years) of the stock option on the exercise date. The remaining term is measured as the difference } \\
\text { between the expiration date and the exercise date. The summary statistics are organized by the } \\
\text { two-digit firm-level SIC categories as reported by CRSP. }\end{array}$} \\
\hline
\end{tabular}

Table 4 reports the summary statistics of the stock price to the exercise price ratio in the sample data. There is a difference in the ratios both across and within sectors. The highest ratios reflect run-ups in the stock market during our sample period. Specifically, these ratios stem from market run-ups during the end of the 1990s and the beginning of 2000. In general, 
the option exercise patterns present evidence on the persistence of early exercise behavior along with considerable heterogeneity both within and across sectors. These findings are consistent with the findings of Carpenter et al. (2009) and Bettis et al (2005).

\begin{tabular}{|c|c|c|c|c|c|c|}
\hline \multicolumn{7}{|c|}{ Table 4: The $\mathrm{S} / \mathrm{X}$ ratio on the exercise date } \\
\hline Industry & Average & SD & Max & Min & $\begin{array}{c}\text { 1st } \\
\text { quartile }\end{array}$ & $\begin{array}{c}\text { 4th } \\
\text { quartile }\end{array}$ \\
\hline Full sample & 2.877 & 3.114 & 39.767 & 1.001 & 1.381 & 3.278 \\
\hline Food and kindred products & 2.603 & 0.903 & 3.972 & 1.358 & 1.613 & 3.393 \\
\hline Paper and allied products & 2.512 & 0.962 & 5.590 & 1.257 & 1.868 & 2.563 \\
\hline Printing, publishing, and allied industries & 2.964 & 0.671 & 4.339 & 1.654 & 2.619 & 3.500 \\
\hline Chemicals and allied products & 1.958 & 0.600 & 5.152 & 1.012 & 1.485 & 2.359 \\
\hline $\begin{array}{l}\text { Industrial and commercial machinery and } \\
\text { computer equipment }\end{array}$ & 3.339 & 3.314 & 39.767 & 1.006 & 1.551 & 4.091 \\
\hline $\begin{array}{l}\text { Electronic and other electrical equipment } \\
\text { and components, except computer } \\
\text { equipment }\end{array}$ & 2.871 & 3.311 & 37.758 & 1.001 & 1.281 & 3.414 \\
\hline $\begin{array}{l}\text { Measuring, analyzing, and controlling } \\
\text { instruments; photographic, medical and } \\
\text { optical goods; watches and clocks }\end{array}$ & 1.892 & 1.250 & 30.415 & 1.010 & 1.368 & 1.869 \\
\hline Communications & 2.393 & 2.577 & 28.980 & 1.009 & 1.548 & 2.525 \\
\hline Wholesale trade-durable goods & 2.159 & 0.894 & 5.531 & 1.093 & 1.744 & 2.196 \\
\hline Depository institutions & 1.562 & 0.184 & 1.878 & 1.019 & 1.440 & 1.695 \\
\hline Business services & 3.926 & 4.476 & 26.158 & 1.001 & 1.471 & 4.242 \\
\hline $\begin{array}{l}\text { Engineering, accounting, research, } \\
\text { management, and related services }\end{array}$ & 2.128 & 0.822 & 8.281 & 1.028 & 1.580 & 2.395 \\
\hline Entire sample, employees & 2.860 & 3.138 & 39.767 & 1.001 & 1.371 & 3.236 \\
\hline $\begin{array}{l}\text { Entire sample, executives (Directors and } \\
\text { Officers) }\end{array}$ & 3.342 & 2.301 & 25.000 & 1.033 & 1.757 & 4.176 \\
\hline Entire sample, exercise (cash) & 4.316 & 5.774 & 33.163 & 1.022 & 1.412 & 3.883 \\
\hline Entire sample, SDS (same day sale) & 2.865 & 3.080 & 39.767 & 1.001 & 1.381 & 3.273 \\
\hline
\end{tabular}

\section{Estimation of the nondiversification measure and the ESO value}

We use the proprietary data set of ESOs grants and exercise records and reverseengineering techniques to estimate the ESO value using the private pricing model. The estimation includes two stages, based on employee-by-employee exercise records: In the first stage we estimate the nondiversification measure $\delta$ based on the stock price and the stock 
option characters (such as the standard deviation and risk free rate for each stock option) on the ESO exercise date. In the second stage we calibrate the nondiversification estimation along with the stock option characters, and calculate the ESO value using the private pricing model relative to a plain vanilla stock option value using BS model on the grant date.

Table 5 uses the reported stock prices on the exercise date to calculate the implied nondiversification measure $\delta$ using the specific characters of each stock option exercise record: risk free rate, volatility, dividend yield, vesting and exit rate. ${ }^{18}$ The ratios are divided to groups according to the CRSP SIC codes, and in addition an average data is calculated to rank and file employees relative to executives and to exercise records in which the employee continued to hold the stock relative to exercise records in which the stock acquired is sold immediately (cashless exercise).

\footnotetext{
${ }^{18}$ We do not use vesting here because if the stock option can be exercised it means that it's after vesting.
} 


\begin{tabular}{|c|c|c|c|c|c|c|}
\hline Industry & Average & SD & Max & Min & $\begin{array}{c}\text { 1st } \\
\text { quartile }\end{array}$ & $\begin{array}{c}\text { 4th } \\
\text { quartile }\end{array}$ \\
\hline Full sample & 0.025 & 0.036 & 0.474 & 0.000 & 0.005 & 0.030 \\
\hline Food and kindred products & 0.009 & 0.007 & 0.027 & 0.002 & 0.004 & 0.014 \\
\hline Paper and allied products & 0.010 & 0.006 & 0.035 & 0.003 & 0.007 & 0.011 \\
\hline Printing, publishing, and allied industries & 0.008 & 0.004 & 0.019 & 0.004 & 0.005 & 0.009 \\
\hline Chemicals and allied products & 0.021 & 0.031 & 0.285 & 0.001 & 0.007 & 0.025 \\
\hline $\begin{array}{l}\text { Industrial and commercial machinery and computer } \\
\text { equipment }\end{array}$ & 0.020 & 0.031 & 0.414 & 0.000 & 0.003 & 0.025 \\
\hline $\begin{array}{l}\text { Electronic and other electrical equipment and } \\
\text { components, except computer equipment }\end{array}$ & 0.032 & 0.044 & 0.469 & 0.000 & 0.006 & 0.039 \\
\hline $\begin{array}{l}\text { Measuring, analyzing, and controlling instruments; } \\
\text { photographic, medical and optical goods; watches and } \\
\text { clocks }\end{array}$ & 0.023 & 0.026 & 0.319 & 0.000 & 0.010 & 0.025 \\
\hline Communications & 0.023 & 0.029 & 0.353 & 0.000 & 0.008 & 0.025 \\
\hline Wholesale trade-durable goods & 0.030 & 0.028 & 0.160 & 0.004 & 0.016 & 0.028 \\
\hline Depository institutions & 0.026 & 0.027 & 0.299 & 0.007 & 0.015 & 0.026 \\
\hline Business services & 0.023 & 0.033 & 0.474 & 0.000 & 0.005 & 0.029 \\
\hline $\begin{array}{l}\text { Engineering, accounting, research, management, and } \\
\text { related services }\end{array}$ & 0.018 & 0.021 & 0.291 & 0.000 & 0.008 & 0.021 \\
\hline Entire sample, employees & 0.026 & 0.036 & 0.474 & 0.000 & 0.005 & 0.031 \\
\hline Entire sample, executives (Directors and Officers) & 0.016 & 0.021 & 0.328 & 0.000 & 0.004 & 0.022 \\
\hline Entire sample, exercise (cash) & 0.027 & 0.042 & 0.328 & 0.000 & 0.004 & 0.032 \\
\hline Entire sample, SDS (same day sale) & 0.025 & 0.036 & 0.474 & 0.000 & 0.005 & 0.030 \\
\hline \multicolumn{7}{|c|}{$\begin{array}{l}\text { This table reports the nonmarketability estimation on the exercise date. We estimate nonmarketability using the specifi } \\
\text { characters of each option record. Time to maturity is measured as the number of years between the exercise date and the } \\
\text { original expiration date of the option grant. Annual risk-free rate is adjusted according to the share's currency. Volatility i } \\
\text { estimated by historical volatility of the share. The summary statistics are computed over all the exercise records in the } \\
\text { sample period and grouped using two-digit firm-level SIC categories as reported in CRSP. }\end{array}$} \\
\hline
\end{tabular}

The mean nondiversification measure in the entire sample (Table 5) is around 0.025 , with a similar tendency within the SIC sectors, except the food and kindred products and the paper and allied products (SIC codes 20 and 26, respectively). In addition, according to Table 5 results executives have a lower nondiversification measure relative to rank and file employees. It means that, ceteris paribus, executives tend to exercise their stock options later (or closer to expiration) than rank and file employees.

Table 6 presents the private pricing model estimations of at-the-money ESOs relative to plain vanilla stock options values using BS model on the grant date. These estimations calibrate the nondiversification measure from Table 5 (calculated on the exercise date) with the annual 
risk free rate, historical volatility, contractual option life, vesting period and dividend yield-all on the grant date-to calculate the ESO private value. The at-the-money plain vanilla stock option value was calculated using the same annual risk free rate, historical volatility, contractual option life and dividend yield (and exercise price).

\begin{tabular}{|c|c|c|c|c|c|c|}
\hline \multicolumn{7}{|c|}{$\begin{array}{l}\text { Table 6: ESO private value relative to Black-Scholes value (in } \\
\text { percentage) on the grant date }\end{array}$} \\
\hline Industry & Average & SD & Max & Min & $\begin{array}{c}\text { 1st } \\
\text { quartile }\end{array}$ & $\begin{array}{c}\text { 4th } \\
\text { quartile }\end{array}$ \\
\hline Full sample & $48.23 \%$ & $29.62 \%$ & $99.97 \%$ & $0.00 \%$ & $22.01 \%$ & $74.24 \%$ \\
\hline Food and kindred products & $69.06 \%$ & $16.17 \%$ & $89.36 \%$ & $32.05 \%$ & $57.79 \%$ & $82.24 \%$ \\
\hline Paper and allied products & $68.32 \%$ & $13.21 \%$ & $88.35 \%$ & $25.40 \%$ & $62.34 \%$ & $76.02 \%$ \\
\hline $\begin{array}{l}\text { Printing, publishing, and allied } \\
\text { industries }\end{array}$ & $65.30 \%$ & $9.82 \%$ & $76.42 \%$ & $37.53 \%$ & $60.05 \%$ & $73.31 \%$ \\
\hline Chemicals and allied products & $50.35 \%$ & $24.21 \%$ & $93.75 \%$ & $0.00 \%$ & $31.24 \%$ & $70.02 \%$ \\
\hline $\begin{array}{l}\text { Industrial and commercial } \\
\text { machinery and computer equipment }\end{array}$ & $57.97 \%$ & $30.62 \%$ & $99.97 \%$ & $0.00 \%$ & $29.92 \%$ & $85.37 \%$ \\
\hline $\begin{array}{l}\text { Electronic and other electrical } \\
\text { equipment and components, except } \\
\text { computer equipment }\end{array}$ & $41.21 \%$ & $30.37 \%$ & $99.80 \%$ & $0.00 \%$ & $13.27 \%$ & $70.14 \%$ \\
\hline $\begin{array}{l}\text { Measuring, analyzing, and } \\
\text { controlling instruments; } \\
\text { photographic, medical and optical } \\
\text { goods; watches and clocks }\end{array}$ & $47.15 \%$ & $23.59 \%$ & $98.87 \%$ & $0.00 \%$ & $32.45 \%$ & $60.94 \%$ \\
\hline Communications & $43.73 \%$ & $24.55 \%$ & $99.17 \%$ & $0.00 \%$ & $28.47 \%$ & $62.45 \%$ \\
\hline Wholesale trade-durable goods & $30.92 \%$ & $18.55 \%$ & $74.89 \%$ & $0.00 \%$ & $21.45 \%$ & $39.14 \%$ \\
\hline Depository institutions & $44.78 \%$ & $17.30 \%$ & $73.96 \%$ & $0.00 \%$ & $36.69 \%$ & $56.42 \%$ \\
\hline Business services & $48.47 \%$ & $28.91 \%$ & $99.46 \%$ & $0.00 \%$ & $26.03 \%$ & $74.18 \%$ \\
\hline $\begin{array}{l}\text { Engineering, accounting, research, } \\
\text { management, and related services }\end{array}$ & $50.92 \%$ & $24.96 \%$ & $97.57 \%$ & $0.00 \%$ & $33.22 \%$ & $68.91 \%$ \\
\hline Entire sample, employees & $47.98 \%$ & $29.68 \%$ & $99.97 \%$ & $0.00 \%$ & $21.68 \%$ & $74.05 \%$ \\
\hline $\begin{array}{l}\text { Entire sample, executives (Directors } \\
\text { and Officers) }\end{array}$ & $55.07 \%$ & $27.00 \%$ & $97.57 \%$ & $0.00 \%$ & $32.96 \%$ & $78.73 \%$ \\
\hline Entire sample, exercise (cash) & $51.28 \%$ & $32.34 \%$ & $99.77 \%$ & $0.00 \%$ & $22.11 \%$ & $80.45 \%$ \\
\hline Entire sample, SDS (same day sale) & $48.20 \%$ & $29.59 \%$ & $99.97 \%$ & $0.00 \%$ & $22.00 \%$ & $74.20 \%$ \\
\hline \multicolumn{7}{|c|}{$\begin{array}{l}\text { This table reports the value of the ESO using the private pricing model relative to a plain vanilla } \\
\text { Black-Scholes value of the ESO on the grant date. The nonmarketability measure was estimated on } \\
\text { the exercise date and calibrated into the model. Time to maturity is measured as the number of } \\
\text { years between the grant date and the original expiration date of the option grant. Annual risk-free } \\
\text { rate is adjusted according to the share's currency. The volatility is estimated by historical volatility } \\
\text { of the stock. The summary statistics are computed over all the exercise records in the sample } \\
\text { period, and grouped using two-digit firm-level SIC categories as reported in CRSP. }\end{array}$} \\
\hline
\end{tabular}


According to Table 6 outcomes, the private ESO value is, on average, about $50 \%$ relative to a plain vanilla BS option value. In the food and kindred products and the paper and allied products (SIC codes 20 and 26, respectively) industries the value is higher is around 65\%. These findings are consistent with the predictions of Meulbroek (2001), that in new economy firms, (with exhibit higher stock volatility) an undiversified manager would assign lower value to his stock options relative to undiversified manager from less volatile industries. Table 6 findings are also consistent with the findings of Ikaheimo et al. (2006), which use the prices of tradable executive stock options, traded at the Helsinki stock exchange after the options are vested (which means these are transferable stock options). By analyzing 27,808 trades, Ikaheimo et al. (2006) show major underpricing of the ESO which can reach over $50 \%$ discount relative to BS value. Since Ikaheimo et al. (2006) examine tradable stock options, the nonmarketability associated with these options should be less comparing to the standard case of untradeable stock options (which is the case of the stock options in Tamir-Fishman sample). It implies that the untradeable stock options the discount should be higher than the one found by Ikaheimo et al. (2006). In addition, pursuance to Table 5, Table 6 results ascribes higher option values to executives compared to ESO values to non-executive employees. Overall, these results point out on a relative high discount of equity based compensation.

\section{Private pricing model: Numerical implications}

We compare the results of the private pricing model to the empirical findings presented in the literature. These comparisons are intended to validate the notion that the private pricing model is aligned with empirical findings, indicating that the model is suitable to value ESOs.

\section{Calculating the stock price to exercise price ratio on the exercise date}

Our model allows us to calculate the implied ratio of the stock price to exercise price on the exercise date (this ratio is known as the Hull and White (2004) multiple M). Assuming that the employee exercises the stock option when the private value is equals to the intrinsic value we use the firm's stock price on this date and derive the stock price to the exercise price ratio. Figure 4 presents the change in the stock price to exercise price ratio, as a function of the nondiversification measure $\delta$ for different stock option characteristics. 


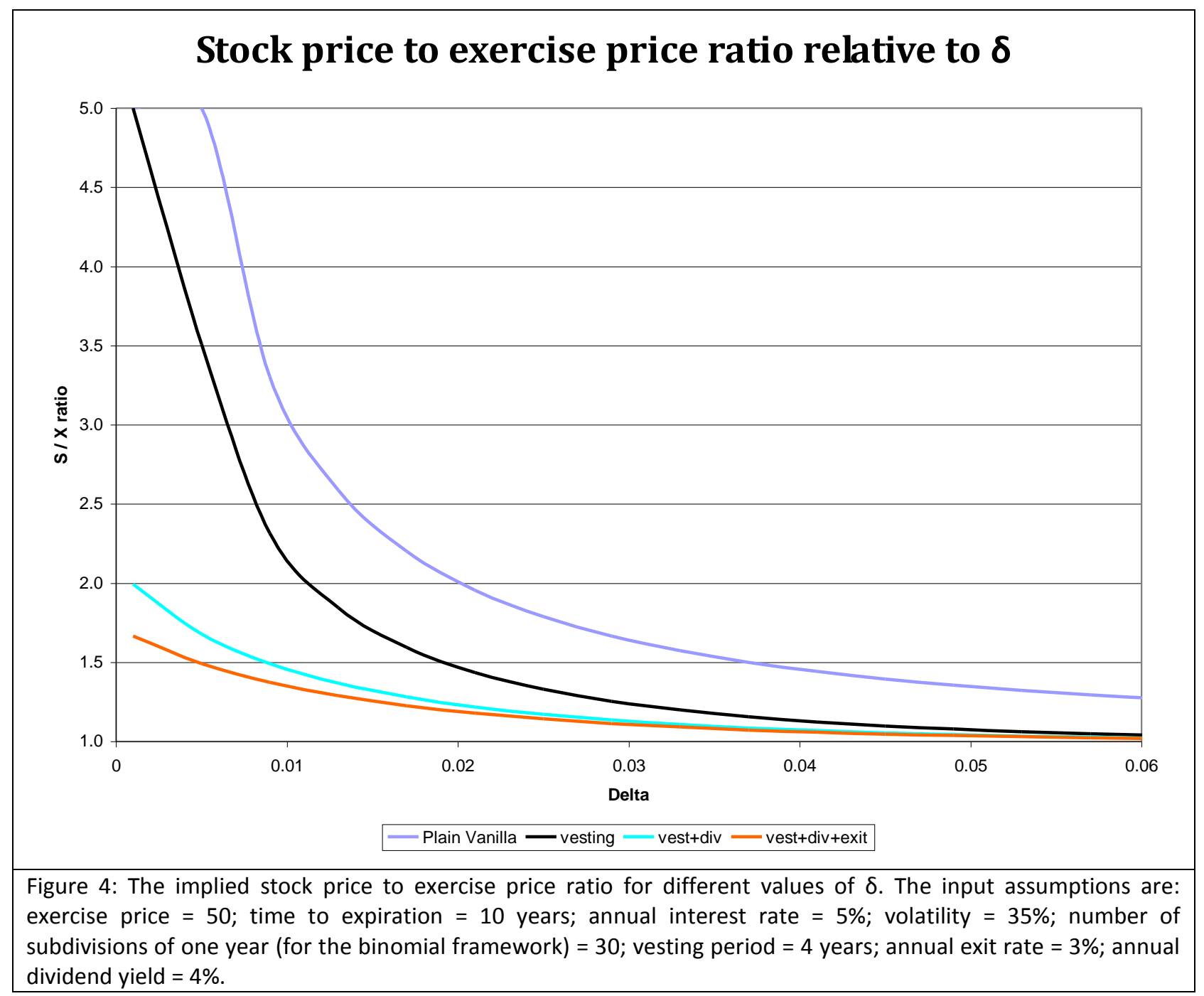

Table 7 summarizes the empirical findings regarding the stock to exercise price ratio. It suggests that the implied ratio, calculated using the private pricing model, is within the range of the empirical findings. The findings presented in Table 1 do not include the findings reported by Carpenter et al. (2009), which provide extensive documentation regarding the stock/exercise price across industries, and report similar results. Overall, the data indicates a large variation in the ratios, both across and within sectors, with very high ratios reflecting the run-up in the stock market during our sample period. ${ }^{19}$

\footnotetext{
${ }^{19}$ Possible explanations are the variation in the sample period and in the sample population.
} 


\begin{tabular}{|c|c|c|c|c|c|}
\hline \multicolumn{6}{|c|}{ Table 7: Empirical data on the stock price to exercise price ratio ${ }^{20}$} \\
\hline \multicolumn{6}{|c|}{ Huddart and Lang (1996): } \\
\hline Average & Median & Quartile & Quartile & Sample & Sample period \\
\hline 2.2 & 1.6 & 1.283 & 2.5 & All employees & Late 80 s - early $90 \mathrm{~s}$ \\
\hline \multicolumn{6}{|c|}{ Carpenter (1998): } \\
\hline Average & Median & Quartile & Quartile & S.D. Sample & Sample period \\
\hline 2.75 & 2.47 & 1.15 & 8.32 & 1.42 Executives & $1979-1994$ \\
\hline \multicolumn{6}{|c|}{ Bettis, Bizjak, Lemmon (2005) } \\
\hline Average & Median & 1st percentile & 99th percentile & Sample & Sample period \\
\hline 3.55 & 2.57 & 1.04 & 17.34 & Corporate insiders & $1996-2002$ \\
\hline
\end{tabular}

Even after considering the variation in the stock to exercise ratio, we can see that the private pricing model estimation is within the range of all the studies that use empirical data.

\section{Calculating the private value to BS value ratio on the exercise date}

In addition to the findings regarding the stock/exercise price ratio, an additional examination that can be implemented is comparing the remaining BS value, relative to the intrinsic value (or private value) on the exercise date. We show that this ratio, calculated using the private pricing model, is also within the range of the empirical findings.

Figure 5 presents the forgone value under early exercise of the ESO (in percentages). This value is calculated in BS terms, and is calculated as $1-\frac{\text { Intrinsic value }}{\text { BS value }}$. Since this ratio is calculated on the (early) exercise date, we use a shorter option term.

\footnotetext{
${ }^{20}$ Hemmer, Matsunaga and Shevlin (1996) report similar findings regarding this ratio.
} 


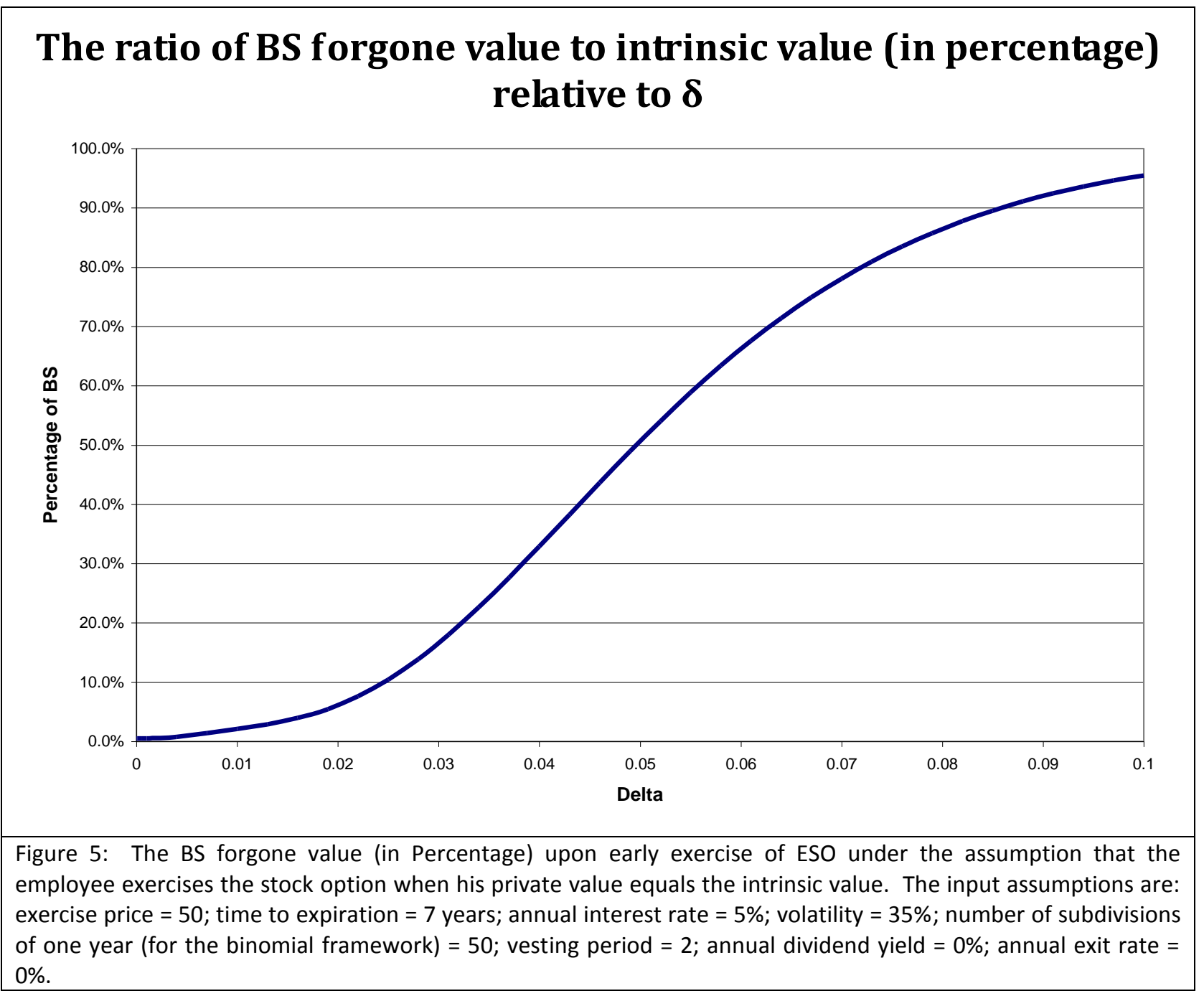

Our computations show that the value the employee forfeits changes dramatically as a function of his nondiversification measure. For a forfeit of $10-20 \%$ of BS value, the nondiversification measure $\delta$ is between 0.025-0.03.

Table 8 reports the empirical findings regarding the ESO intrinsic value to the remaining BS option value on the (early) exercise date. The sample data indicates a large variation in this ratio as well. However, while Bettis, Bizjak and Lemmon (2005) measure this ratio on the exercise date, Huddart and Lang (2003) measure it for an average month. ${ }^{21}$ Thus, Bettis et al.'s (2005) data is more relevant to our examination.

\footnotetext{
21 Huddart and Lang (2003) used the Barone-Adesi and Whaley model (and not the Black-Scholes model) to estimate the ESO value at time $t$.
} 


\begin{tabular}{|c|c|c|c|c|c|c|}
\hline \multicolumn{7}{|c|}{$\begin{array}{c}\text { Table 8: Empirical data on the ratio of intrinsic value to the } \\
\text { remaining American option value }\end{array}$} \\
\hline \multicolumn{7}{|c|}{ Huddart and Lang $(2003)^{22}$ : } \\
\hline Average & Median & Quartile & Quartile & S.D. & Sample & Sample period \\
\hline 0.7423 & 0.7915 & 0.5544 & 0.965 & 0.2308 & All employees & 1985 - 1994 \\
\hline \multicolumn{7}{|c|}{ Bettis, Bizjak, Lemmon (2005) } \\
\hline Average & Median & 1st percentile & 99th percentile & Sample & & Sample period \\
\hline 0.9 & 0.84 & 0.12 & 1 & Corpor & ate insiders & $1996-2002$ \\
\hline
\end{tabular}

Another interesting finding in this respect is the one made by Zions Bancorp. Zions Bancorp issues securities that replicate the cash flow generated from ESOs and sell this cash flow in an auction. The auction results show that the replicating security yield lower values than the BS values, using the same assumptions on the issuance date. For example, the price of the replication instrument in one of the auctions was $14 \%$ lower than the BS value. ${ }^{23}$ However, the BS value was calculated using expected life, rather than the time to expiration of the stock option. Using the time to expiration of the option would yield a higher discount.

\section{Conclusion and summary}

This paper examines the valuation of employee stock options. Our private pricing model provides a simple framework for pricing these options using private state prices.

The private pricing model has two computational advantages over existing approaches in pricing ESOs. First, compared to lattice and continuous-time models which employ an arbitrary algorithm to explain early exercise, the private pricing model provides an endogenous explanation of ESO early exercise. Compared to the utility maximizing models which provide endogenous early exercise decision, the private pricing model can be viewed as a model that incorporates the utility model parameters into a single factor and thus provides a simplified and more flexible approach to describe exercise behavior and to compute the ESO value. The second advantage of the private pricing model in pricing ESOs is that we are able to quantify the nondiversification effects.

We show that the use of the private pricing model is aligned with empirical findings in studies on ESOs databases: The ratio of the stock price to exercise price and the value forgone (in percentage) comparing to Black-Scholes value (both on the exercise date) are within empirical estimations range. The employee tends to exercise earlier as more restrictions are added to the stock options, if he is more undiversified and when the stock's volatility is higher.

\footnotetext{
${ }^{22}$ Huddart and Lang (1996) also report this ratio for the same sample, but the data is presented for each firm separately.

${ }^{23}$ See https://www.auctions.zionsdirect.com/auction/337/prospectus, page 52.
} 
The second part of the paper uses a proprietary data base to estimate the nondiversification measure $\delta$. We use the stock price on the exercise date for each ESO exercise record, accompanied by the specific characteristics of each exercise record-such as the annual risk free rate, historical volatility and remaining time to maturity-and estimates the nondiversification measure for each exercise record. We calibrate the nondiversification measure along with other stock option characters on the grant date and estimate the discount associated with the private pricing model relative to a plain vanilla stock option, calculated using the BS option pricing model. We find that the average discount relative to the BS value is around $50 \%$ of the stock option. 


\section{References}

Benninga, S., Financial Modeling, $3^{\text {rd }}$ edition, MIT Press, 2008.

Benninga, S., Helmantel, M., Sarig, O., 2005. The Timing of Initial Public Offering. Journal of Financial Economics 75, 115-132.

Bettis, C., Bigjak, J., Lemmon, M., 2005. Exercise Behavior, Valuation, and the Incentive Effects of Employee Stock Options. Journal of Financial Economics 76, 445-470.

Bick, A. 1987. On the Consistency of the Black-Scholes Model with a General Equilibrium Framework. Journal of Financial and Quantitative Analysis 22, 259-275.

Black, F., Scholes, M., 1973. The Pricing of Options and Corporate Liabilities. Journal of Political Economy 81, 637-659.

Brenner, M., Eldor, R., Hauser, S., 2001. The price of options illiquidity. The Journal of Finance 26, 789- 806.

Carpenter, J., 1998. The Exercise and Valuation of Executive Stock Options. Journal of Financial Economics 48(2), 127-158.

Carpenter, J., Stanton, R., Wallace, N., 2009. Estimation of Employee Stock Option Exercise Rates and Firm Costs. Available at http://hdl.handle.net/2451/27844.

Chance, D., Yang, T.H., 2004. Expected Utility Valuation of Executive Stock Options in a Binomial Framework: A Comparative Analysis. Available at SSRN: http://papers.ssrn.com/sol3/papers.cfm?abstract id=561023.

Cox, J., Ross, S., Rubinstein, M., 1979. Option Pricing: A Simplified Approach. Journal of Financial Economics 7, 229-264.

Damodaran, A., 2005. Marketability and Value: Measuring the Illiquidity Discount. Available at http://pages.stern.nyu.edu/ adamodar.

Eldor, R., Hauser, S., Kahn, M., Kamara, A., 2006. The Nontradability Premium of Derivatives Contracts. The Journal of Business 79(4), 2067-2097.

Grasselli, M., 2005. Nonlinearity, Correlation and the Valuation of Employee Options. Working paper, McMaster University.

Huddart, S., 1994. Employee Stock Options. Journal of Accounting and Economics 18(2), 207231.

Huddart, S., Lang, M., 1996. Employee Stock Option Exercises: An Empirical Analysis. Journal of Accounting and Economics 21 (1996), 5-43.

Huddart, S., Lang, M., 2003. Information Distribution within Firms: Evidence from Stock Option exercises. Journal of Accounting and Economics 34, 3-31.

Hull, J., 2008. Options, Futures, and Other Derivatives. $7^{\text {th }}$ Edition, Prentice-Hall.

Hull, J., White, A., 2004. How to Value Employee Stock Options, Financial Analysts Journal 60, 114-119. 
Ikaheimo, S., Kousa, N., Puttonen, V., 2006. 'The True and Fair Value' of Executive Stock Option Valuation. European Accounting Review 15(3), 351-366.

Leon, A., Vaello-Sebastia, A., 2009. American GARCH Employee Stock Option Valuation. Journal of Banking and Finance 33, 1129-1143.

Meulbroek, L., 2001. The Efficiency of Equity-Link Compensation: Understanding the Full Cost of Awarding Executive Stock Options. Financial Management 30(2), 5-30.

Oyer, P., Schaefer, S., 2005. Accounting, Governance, and Broad Base Stock-Option Grants. Journal of Financial Intermediation 15, 511-534. 